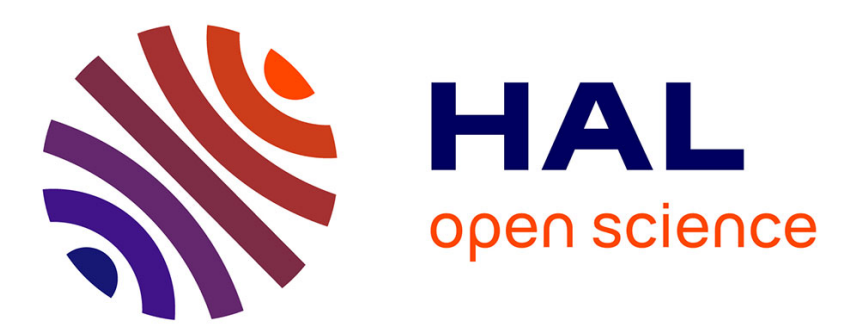

\title{
Hydrologic effects on riparian vegetation in a boreal river: an experiment testing climate change predictions
}

Lotta Ström, Roland Jansson, Christer Nilsson, Mats E. Johansson, Shaojun Xiong

\section{- To cite this version:}

Lotta Ström, Roland Jansson, Christer Nilsson, Mats E. Johansson, Shaojun Xiong. Hydrologic effects on riparian vegetation in a boreal river: an experiment testing climate change predictions. Global Change Biology, 2010, 17 (1), pp.254. 10.1111/j.1365-2486.2010.02230.x . hal-00599516

\section{HAL Id: hal-00599516 https://hal.science/hal-00599516}

Submitted on 10 Jun 2011

HAL is a multi-disciplinary open access archive for the deposit and dissemination of scientific research documents, whether they are published or not. The documents may come from teaching and research institutions in France or abroad, or from public or private research centers.
L'archive ouverte pluridisciplinaire HAL, est destinée au dépôt et à la diffusion de documents scientifiques de niveau recherche, publiés ou non, émanant des établissements d'enseignement et de recherche français ou étrangers, des laboratoires publics ou privés. 


\section{Global Change Biology}

\section{Hydrologic effects on riparian vegetation in a boreal river: an experiment testing climate change predictions}

\begin{tabular}{|c|c|}
\hline Journal: & Global Change Biology \\
\hline Manuscript ID: & GCB-10-0021 \\
\hline Wiley - Manuscript type: & Primary Research Articles \\
\hline $\begin{array}{r}\text { Date Submitted by the } \\
\text { Author: }\end{array}$ & 08-Jan-2010 \\
\hline Complete List of Authors: & $\begin{array}{l}\text { Ström, Lotta; Umeå University, Department of Ecology and } \\
\text { Environmental Science } \\
\text { Jansson, Roland; Umeå University, Department of Ecology and } \\
\text { Environmental Science } \\
\text { Nilsson, Christer; Umeå University, Department of Ecology and } \\
\text { Environmental Science } \\
\text { Johansson, Mats; County Administration of Västerbotten } \\
\text { Xiong, Shaojun; Swedish University of Agricultural Sciences, Unit of } \\
\text { Biomass Technology and Chemistry }\end{array}$ \\
\hline Keywords: & $\begin{array}{l}\text { Biomass, Climate change, Flooding, Productivity, Reciprocal } \\
\text { transplant experiment, River banks, Species composition, Species } \\
\text { richness }\end{array}$ \\
\hline Abstract: & $\begin{array}{l}\text { Climate change is expected to alter the magnitude and variation of } \\
\text { flow in streams and rivers, hence providing new conditions for } \\
\text { riverine communities. We evaluated plant ecological responses to } \\
\text { climate change by transplanting turfs of riparian vegetation to new } \\
\text { elevations in the riparian zone, thus simulating expected changes in } \\
\text { water-level variation, and monitored the results over } 6 \text { years. Turfs } \\
\text { moved to higher elevations decreased in biomass and increased in } \\
\text { species richness, whereas turfs transplanted to lower elevations } \\
\text { gained biomass but lost species. Transplanted plant communities } \\
\text { were inert in their response to new hydrologic conditions. After } 6 \\
\text { years, biomass of transplanted turfs did not differ statistically from } \\
\text { target level controls, but species richness and species composition } \\
\text { of transplants were intermediate between original and target levels. } \\
\text { By using projections of future stream flow according to IPCC } \\
\text { climate change scenarios, we predict likely changes to riparian } \\
\text { vegetation in boreal rivers. Climate-driven hydrologic changes are } \\
\text { predicted to result in narrower riparian zones along the studied } \\
\text { Vindel River in northern Sweden towards the end of the } 21 \text { st } \\
\text { century. Present riparian plant communities are projected to be } \\
\text { replaced by terrestrial communities at high elevations as a result of } \\
\text { lower-magnitude spring floods, and by amphibious or aquatic }\end{array}$ \\
\hline
\end{tabular}


communities at low elevations as a result of higher autumn and winter flows. Less area available to riparian plants is expected to result in fewer species, even if no species lose their hydrologic niches. Changes to riparian vegetation may be larger in other boreal climate regions: snow-melt fed spring floods are predicted to disappear in southern parts of the boreal zone, which would result in considerable loss of riparian habitat. Our study emphasizes the importance of long-term ecological field experiments given that plant communities often respond slowly and in a non-linear fashion to external pressures.

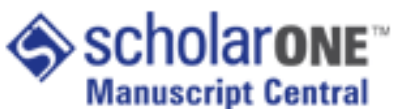

Manuscript Central 


\title{
Hydrologic effects on riparian vegetation in a boreal river: an
}

\section{experiment testing climate change predictions}

\author{
Running title: Climate-change effects on riparian vegetation \\ LOTTA STRÖM*, ROLAND JANSSON*, CHRISTER NILSSON*, MATS E. \\ JOHANSSON $^{*, \dagger}$ and SHAOJUN XIONG ${ }^{*}, \dagger$ \\ * Landscape Ecology Group, Department of Ecology and Environmental Science, Umeå \\ University, SE-901 87 Umeå, Sweden, ${ }^{\dagger}$ Present address: County Administration of \\ Västerbotten, SE-901 86 Umeå, Sweden, ${ }^{\ddagger}$ Present address: Unit of Biomass Technology and \\ Chemistry, Swedish University of Agricultural Sciences, SE-904 03 Umeå, Sweden
}

\begin{abstract}
Corresponding author: Lotta Ström, Landscape Ecology Group, Department of Ecology and Environmental Science, Umeå University, SE-901 87 Umeå, Sweden, telephone +46-907867151:, fax: +46-90-7867860, e-mail: lotta.strom@emg.umu.se
\end{abstract}

Keywords: biomass, climate change, flooding, productivity, reciprocal transplant experiment, river banks, species composition, species richness, water table, wetlands 


\begin{abstract}
Climate change is expected to alter the magnitude and variation of flow in streams and rivers, hence providing new conditions for riverine communities. We evaluated plant ecological responses to climate change by transplanting turfs of riparian vegetation to new elevations in the riparian zone, thus simulating expected changes in water-level variation, and monitored the results over 6 years. Turfs moved to higher elevations decreased in biomass and increased in species richness, whereas turfs transplanted to lower elevations gained biomass but lost species. Transplanted plant communities were inert in their response to new hydrologic conditions. After 6 years, biomass of transplanted turfs did not differ statistically from target level controls, but species richness and species composition of transplants were intermediate between original and target levels. By using projections of future stream flow according to IPCC climate change scenarios, we predict likely changes to riparian vegetation in boreal rivers. Climate-driven hydrologic changes are predicted to result in narrower riparian zones along the studied Vindel River in northern Sweden towards the end of the $21^{\text {st }}$ century. Present riparian plant communities are projected to be replaced by terrestrial communities at high elevations as a result of lower-magnitude spring floods, and by amphibious or aquatic communities at low elevations as a result of higher autumn and winter flows. Less area available to riparian plants is expected to result in fewer species, even if no species lose their hydrologic niches. Changes to riparian vegetation may be larger in other boreal climate regions: snow-melt fed spring floods are predicted to disappear in southern parts of the boreal zone, which would result in considerable loss of riparian habitat. Our study emphasizes the importance of long-term ecological field experiments given that plant communities often respond slowly and in a non-linear fashion to external pressures.
\end{abstract}




\section{Introduction}

Global mean annual temperature has increased by $0.7^{\circ} \mathrm{C}$ during the $20^{\text {th }}$ century (IPCC 2007). Models of climate change predict that temperature will continue to increase during the $21^{\text {st }}$ century. The highest warming will take place at high northern latitudes (IPCC 2007), calling for studies of how northern ecosystems will respond. At the regional scale, species range shifts are predicted (Saetersdal et al. 1998; Thuiller et al. 2005; Post et al. 2009), but to understand ecosystem-level responses, changes in local environmental conditions need also to be considered.

Warmer climates will likely result in more precipitation in general and less precipitation falling as snow in high northern latitudes, altering the hydrology of streams and rivers (Andréasson et al. 2004; IPCC 2007; Woo et al. 2007). Stream-flow regimes in the boreal zone are strongly seasonally variable. In natural conditions they are characterized by a spring flood peak with the highest levels of the year driven by snowmelt, followed by lower summer discharge (Woo et al. 2007). Regionally, summer and autumn rains might create flood peaks but during winter the flow is low, primarily fed by groundwater discharge. A warmer climate will generally increase winter discharge in all types of boreal rivers since more precipitation will fall as rain (Andréasson et al. 2004; Woo et al. 2007). Earlier snowmelt will also result in earlier spring floods of lower amplitude. In accordance with these expectations, annual stream flow in high northern rivers has increased in recent decades (Peterson et al. 2002).

The seasonal timing and amount of flow variation vary with latitude, degree of climate continentality, topography and influence of buffering waterbodies, and thus the response to climate change will vary among rivers and regions (Woo et al. 2007). In Sweden the temperature is expected to increase by an average of 2.5 to $4.6^{\circ} \mathrm{C}$ by the year 2100 
Climate-driven hydrologic changes are expected to change riverine communities since they are controlled by the magnitude and variation in flow (Décamps 1993; Naiman \& Décamps 1997; Poff et al. 1997). We focused on riparian ecosystems, which are unusually complex, dynamic, and diverse, and possess numerous economic, societal, and biological values (Sharitz et al. 1992; Naiman et al. 2002). These qualities are all maintained by regular floods, and might thus change as a result of climate alterations. Riparian plant communities are structured by differences in the hydrologic niches of species (Silvertown et al. 1999). Substantial changes in riparian vegetation may take place without altering the mean annual flow, as riparian vegetation is especially sensitive to changes in minimum and maximum flows (Auble et al. 1994). In boreal rivers, riparian vegetation is vertically zoned according to the flooding tolerance and moisture requirements of species (Auble et al. 1994; Johansson \& Nilsson 2002). Floods pose stresses and disturbances to riparian plants by affecting physiological processes such as photosynthesis and respiration (Kozlowski 1984; Vervuren et al. 2003; van Eck et al. 2004; Mommer \& Visser 2005; Renöfält et al. 2007), by removing plant biomass (Bendix 1999) or burying plants under deposits of sediment or organic matter 
(Xiong \& Nilsson 1997). These processes may enhance species richness by suppressing dominants and enhancing the colonization and survival of competitively subordinate species (Day et al. 1989, Pollock et al. 1998). However, along gradients of increasing stress and disturbance, species richness may decline as the challenges of flooding exceed the capacity of species. Local species richness peaks in the mid-elevation riparian shrub zone (Pollock et al. 1998), but the pool of riparian species is largest close to the annual high-water level (Nilsson 1983), where flood duration is short and species lacking physiological adaptations to flooding may grow. Plant productivity also varies predictably with flood frequency and duration, with biomass production generally increasing from spring-flood maintained communities to sedgedominated communities experiencing prolonged periods of inundation (Dwire et al. 2004). To be able to predict how riparian vegetation will respond to climate change we addressed the following questions:

(1) How will changes in flood duration and frequency affect riparian species richness? According to hydrological models the upper part of the riparian zone will be flooded less frequently while the lower part will experience longer periods of inundation. Changes in flood disturbance can both increase and decrease species richness depending on where the community is situated along the disturbance continuum (e.g. Pollock et al. 1998). To be able to predict changes in species richness experiments are necessary.

(2) Similarly, how will the hydrologic changes alter biomass production? Biomass is expected to decrease in high to mid elevation riparian forest and shrub communities as a result of lower duration of flooding, but increase at lower elevations dominated by graminoids, where flood duration is expected to increase. This does not take into account that a warmer climate may increase plant biomass production as a result of warmer and longer growing seasons, potentially resulting in more plant litter accumulation, if not limited by water availability or flooding. 
Addressing these questions requires manipulating the frequency and duration of floods. However, experimentally manipulation flow in streams and rivers to test scientific hypotheses are usually not an option. As an alternative, we assessed the effects of climate change on productivity and species richness of riparian plant communities by performing a reciprocal transplant experiment, moving vegetation turfs between different elevations in the riparian zone. This simulated changes in the frequency and duration of floods, and we monitored the responses over 6 years. Reciprocal transplantation is a powerful method to assess the effects of contrasting environments on species, but it has only recently been used to assess responses of plant communities in wetland ecosystems (Toogood et al. 2008). The flow of most rivers is affected by dams and diversions (Nilsson et al. 2005), making it difficult to isolate the effects of climate change on hydrology and ecosystems from effects of land-use. Therefore, we chose to work along the seventh-order Vindel River in northern Sweden, a free-flowing tributary in the Ume River catchment. Our objective was to investigate how floodplain meadow plant communities respond to manipulations in hydrology and litter inputs simulating those expected as a result of future climate change. The experimental design allowed asking how long it will take for plant communities to adjust to new hydrologic conditions. The results will improve our ability to predict how and at what rate vegetation succession will occur on floodplains subject to changes in hydrology and litter inputs as a consequence of climate change. 


\section{Methods}

\section{Study area}

The experiment was conducted on a floodplain meadow along the lower reaches of the freeflowing Vindel River in northern Sweden (N 64 22', E 19 $22^{\prime}$ ). The Vindel River originates in the Scandes mountain range and joins the Ume River about $30 \mathrm{~km}$ from the coast of the Gulf of Bothnia. The catchment area is $12654 \mathrm{~km}^{2}$ of which $5 \%$ are lakes. The river is $455 \mathrm{~km}$ long and the mean annual discharge is $200 \mathrm{~m}^{3} \mathrm{~s}^{-1}$ at the confluence with the Ume River. The discharge is unaffected by dams and diversions and varies between 16 and $1787 \mathrm{~m}^{3} \mathrm{~s}^{-1}$ [mean annual minimum and maximum flows during 1911-2000; data from the Swedish Meteorological and Hydrological Institute (SMHI), Norrköping, Sweden]. The hydrologic regime is characterized by a spring flood peak due to snowmelt in May or June followed by progressively lower water levels during summer and winter. In some years summer and autumn rains and reduced evapotranspiration towards the end of the growing season result in additional flood events.

The river-margin vegetation is distinctly vertically zoned along the entire river. The width and plant zonation and width of vegetation belts can be defined by hydrologic criteria, the upper end of riparian vegetation being equivalent to the spring flood peak level, whereas the lower end of graminoid vegetation is synchronous with average summer low water levels (Wassén 1966; Nilsson 1999). Up to the 1950s and 1960s, most riparian zones along tranquil reaches with fine-grained soils were used for haymaking, favouring plant communities rich in graminoids and herbs. Following abandonment, riparian tree and shrub species have colonized higher elevations of these meadows. The riparian vegetation of the catchment is primarily composed of native species, only a few occurrences of exotic species are known and invasive species are absent (Nilsson 1999, Dynesius et al. 2004). 
The experimental site was located about $70 \mathrm{~km}$ upstream of the confluence between the Vindel and Ume Rivers at 220-230 m a.s.l., and was formerly used for haymaking. The site was selected since it was a fairly large, homogenous riparian meadow with uniform soil grain size consisting of silt, located $2.5 \mathrm{~km}$ upstream of a stream flow gauge. The vegetation at the site was zoned, going from communities dominated by graminoids and herbs with some older birches (Betula pubescens) at the top, to mid elevations dominated by Salix shrubs and graminoids such as Calamagrostis canescens, followed by herbaceous communities dominated by Carex acuta, Calamagrostis canescens and various amphibious species such as Ranunculus reptans at the bottom. The annual growing season (days where the average temperature exceeds $+5^{\circ} \mathrm{C}$ ) is about 150 days (period 1961-1990, SMHI).

\section{Layout of plots and treatments}

A total of 96 plots were distributed at three elevations (Fig. 1), corresponding to the riparian belts of forest, shrub and graminoids (Nilsson 1983). The vertical difference in elevation was $0.55 \mathrm{~m}$ between high and middle plots, and $0.90 \mathrm{~m}$ between middle and low plots. To simulate changes in the flood regime, we transplanted vegetation between elevations in June 2000. Each plot was 70x100 cm in size and was excavated to a depth greater than the rooted zone. Excavated turfs were either carefully put on metal cradles with handles to allow transport to one of the other two elevations with minimal disturbance to the soil, or rotated $180^{\circ}$ and put back into their original positions to evaluate the effect of excavation. The remaining plots were left intact serving as controls. The meadow was divided into four blocks, with two replicates of each treatment per block. Thus, eight replicates that each consisted of 12 plots, i.e. three elevations with the four treatments each (Fig. 1). To simulate increased litter production as a consequence of potential increase in plant productivity due to longer and 
warmer growing seasons, we applied $2000 \mathrm{~g} \mathrm{~m}^{-2}$ of riverborne litter in 2001 and 2002 to half of the plots, one of the replicates in each block. The litter consisted of graminoids and forbs and tree leaves, collected from the riparian zone in nearby reaches of the Vindel River during spring flooding, and dried at room temperature. To keep the applied litter in place a $5 \mathrm{~cm}$ high boundary marker of chicken net was placed around each transplanted plot. To control for an eventual effect on vegetation of this net, it was applied also to plots without added litter. At each level a pressure transducer data logger (Divers, van Essen Instruments Limited) was placed in a well of polystyrene plastic inserted into the ground to measure water level. The difference in ground surface elevation between the loggers was measured using a total station [Geodolite ${ }^{\circledR}$ 506, Geotronics (Trimble), Sweden].

\section{Sampling}

We recorded the frequency of all vascular plant species in each plot using the point touch method (16 points in a $50 \times 50 \mathrm{~cm}$ area, $10 \mathrm{~cm}$ from the edge of the plots, to minimize edge effects; Fig. 1) in August each of the years 2000-2003, 2005 and 2006. Every species touching the stick was recorded once at each point, i.e. the maximum score was 16 per plot. In addition, the presence of any additional species in the plot was recorded. Plant biomass was harvested from subplots $(15 \times 20 \mathrm{~cm})$ nested within each plot (Fig. 1) every year species richness was recorded. After harvest, biomass was dried at $60^{\circ} \mathrm{C}$ for $72 \mathrm{~h}$ and weighed. A subset of 24 plots, representing all treatments, was used for soil sampling for chemical analysis and for measuring soil moisture in 2000-2002. Soil moisture was measured twice each season with plaster cubes in the ground and a soil moisture meter (Model 14.22, Eijkelkamp Agrisearch Equipment, Giesbeek, The Netherlands). Water levels were measured continuously with the data loggers from 2000 to 2003. 
The definition of species follows the taxonomy in Krok and Almquist (1994). In the following cases two or more species were treated as one taxon: Carex juncella $+C$. nigra, Hieracium spp., Hierochlö̈ hirta + H. odorata, Luzula multiflora + L. sudetica, Poa spp., Salix borealis + S. myrsinifolia + S. phylicifolia, and Taraxacum spp.

\section{Data analysis}

Flood duration and frequency for the entire sampling period were quantified by correlating the logger data for the first 4 years with water level measurements made by the SMHI at the gauge in Granåker $2.5 \mathrm{~km}$ downstream in the same tranquil reach; there were no intervening steps or rapids. By comparing instrumental water level records from the Granåker gauge and the experimental site date by date, we constructed a calibration curve by which the gauge data could be used to generate water-level data for each elevation at the experimental site in Strycksele. By interpolating gauge data, we estimated the flooding regime for 2004-2006 for all plots, to supplement the 2000-2003 water-level data.

Simulations of future streamflow for the period 2071-2100 at the nearby gauge were obtained from SMHI (Andréasson et al. 2004). They were calculated using the Rossby Centre Regional Atmosphere-Ocean Model (RCAO) and the runoff model HBV developed by SMHI, using data from two general circulation models: HadAM3H from the Hadley Centre of the UK Meteorological Office and ECHAM4/OPYC3 from the Max-Planck Institute for Meteorology in Hamburg. The general circulation models were run with data according to the A2 and B2 IPCC emission scenarios (Nakicenovic \& Swart 2000), where the A2 scenario results in larger increases in greenhouse gas emissions than the B2 scenario (for detailed description of the simulation models, see Andréasson et al. 2004). We used the same method as above to interpolate projected future water-level records at the gauge to water levels at the study site. 
To evaluate the effects of plot trenching, such as root damage and soil disturbance, we compared plots that were excavated, removed and put back into their original position after rotating $180^{\circ}$, with control plots at the same elevation. We used mixed-effects ANOVAs to analyze variation in biomass and species richness depending on trenching (excavated or not) and elevation (treated as fixed factors), with experimental block as a random factor. The effects of litter addition were evaluated with factorial ANOVA with original and target elevations and litter addition as fixed factors. The tests were performed separately for each year of vegetation sampling. The effect of blocking the experiment was found to be weak (i.e. variation within blocks was similar to between-block variation), and hence we did not include block as a factor in these and subsequent ANOVAs.

To test the effect of changed frequency and duration of flooding on species richness and biomass, we compared turfs that were transplanted to a new elevation with trenched turfs remaining in their original position at both the original and target levels of the transplanted turfs. To evaluate the effect of transplantation, we compared the relative changes in biomass and species richness between 2000 and 2006, as well as differences between treatments the final study year (2006), using one-way ANOVA (with treatment as a factor) and evaluated significant differences among treatments using Tukey's post-hoc tests of honest significant difference $(\alpha=0.05)$. The treatment groups were transplanted turfs and excavated control plots at the origin and target levels of transplants. We made separate tests for each exchange of transplants between levels (i.e. between high and low levels, high and mid levels, and mid and low levels; Fig. 1). When litter addition was included as a factor in these ANOVAs, it did not significantly $(P>0.05)$ affect biomass and species richness, and was dropped during model simplification. 
To evaluate changes in community composition as a result of transplantation, we used Detrended Correspondence Analysis (DCA; ter Braak \& Šmilauer 1998). To analyze whether transplanted turfs resembled the species composition of turfs at the original elevation, or had attained a species composition similar to the target levels, we tested for differences among treatments in the first axis site scores of the DCAs, using one-way ANOVAs with treatment (transplantation vs. excavated controls at the original and target levels) as a factor. We used untransformed species frequency data from the first and final years of the experiment in the analyses, detrended by segments and downweighting rare species. Significant differences among treatments were evaluated using Tukey's post-hoc tests. We made separate tests for each exchange of transplants between levels as above. We also tested for differences in soil moisture between elevations (high, mid and low) in the riparian zone with a one-way ANOVA and Tukey's post-hoc test. All statistical analyses were performed in the statistical package R (R Development Core Team 2006), except for the ordination which was done in Canoco version 4 (ter Braak \& Šmilauer 1998). 


\section{Results}

Present and projected future hydrologic regimes

During the experiment, the low elevation was flooded every year, the mid elevation was flooded in 5 of the 7 years, and the high elevation was only flooded in 2004 and 2005 (Table 1). Flood duration also varied among years (Fig. 2). In 2001, flood duration was twice as long at the low elevation well compared to the other years, or 81 days compared to 16-40 days the other years. Both duration and frequency during the experimental period (2000-2006) were lower compared to the reference period 1961-1990 (Table 1), which is the period used by SMHI as a baseline to calculate future scenarios. The largest difference was at the low elevation well, with 20 days shorter mean flood duration per year during the experiment (Table 1). The projections of future hydrologic conditions predicted shorter flood duration and longer flood return times at the high riparian elevation in 2071-2100 compared to the normal period 1961-1990 (from 2.1 to up to 7.5; Table 1). The mid elevation will also be flooded less often and with less duration, but the changes are smaller. The low elevation is projected to still be flooded every year with similar or longer durations compared to 1961-1990 (Table 1). Soil moisture increased towards lower elevation in the riparian zone (mean $\pm 1 \mathrm{SE}$, high $54.9 \pm 2.2$, mid $61.8 \pm 1.0$, low $67.9 \pm 1.8 ; F=8.5, P=0.002$, one-way ANOVA with elevation as a factor).

\section{Responses of riparian vegetation to changes in hydrology}

The only significant effect of trenching was found on biomass in 2001. This year, biomass in the trenched plots at low elevations was significantly lower than in the controls $(178 \pm 35 \mathrm{~g}$ compared to $554 \pm 84 \mathrm{~g}, P<0.0001$, mixed-effects ANOVA), and the trenched plots at high elevation had significantly more biomass compared to the controls ( $388 \pm 66 \mathrm{~g}$ compared to $219 \pm 42 \mathrm{~g}, P=0.024)$. We found no significant differences between trenched and control plots 
in species richness for any year or elevation $(P>0.05)$. Thus, after an initial biomass response, trenching per se did not significantly affect the vegetation features. In the remaining analyses, we used the trenched plots as controls for the transplantation treatments. Litter addition significantly reduced biomass in 2002, which was the second and last year litter was applied (Table 2), and significantly reduced species richness in 2003. Litter addition reduced biomass and species richness at all elevations in the riparian zone. No statistically significant effects of litter addition were detected in any of the following years.

The overall effect of the transplantation experiment was that turfs transplanted to higher elevations decreased in biomass and increased in species richness, whereas turfs transplanted to lower elevations gained in biomass but lost in species richness (Figs 3-5), although not all changes following transplantation were significant. Turfs transplanted from high to low elevations increased in biomass compared to the high elevation controls and turfs transplanted to mid elevations $(P<0.05$, one-way ANOVA; Fig. 3a). Comparing biomass between years shows that both transplanted turfs and the low-elevation controls decreased substantially in biomass from 2000 to 2001 (Fig. 4a). The low-elevation controls and the turfs transplanted to low elevations successively increased in biomass thereafter, while the turfs transplanted from low to high elevations remained low during the remainder of the experiment. The final year of the experiment, the plots transplanted between high and low elevations did not differ in biomass compared to the target elevation controls, but differed significantly from their original values (Fig. 4a). The relative change in biomass did not differ among plots transplanted between mid and low elevations (Fig. $3 \mathrm{c}$ and e; $P>0.05$ ), and there were no significant differences in biomass between them the last year (Fig. 4b and c). 
We found between four and five times as many species on high and mid elevation controls compared to low elevation controls $(P<0.05$, one-way ANOVAs and Tukey's tests; Fig. 5a and c). In contrast, we found no difference in species richness between high and mid elevations, and turfs transplanted between mid and high elevations did not change in species richness $(P>0.05$; Figs $3 \mathrm{~b}$ and $\mathrm{d}$ and $5 \mathrm{~b})$. Turfs from high elevations lost species when transplanted to low elevations ( $P=0.002$, one-way ANOVA and Tukey's tests), but did not differ from high elevation controls if transplanted to mid elevations $(P>0.05$; Fig. 3b). Transplants originating from the mid elevation did not differ in species from mid-elevation controls, but there was a difference in species-richness change between the ones moved to high vs. low elevations $(P=0.014)$, since turfs moved up gained and turfs moved down lost species (Fig. 3d). Turfs transplanted from low to mid and high elevations gained significantly more species compared to low elevation controls $(P<0.01$; Fig 3f).

The composition of the transplanted plant communities adjusted slowly to the hydrologic conditions at the target elevations: Only the turfs transplanted from high to low elevations were statistically indistinguishable in species richness and composition from low elevation controls 6 years after transplantation (Figs 5a and 6a). In all other cases, species richness or composition still differed significantly. Changes in species richness occurred gradually during the experiment (Fig. 5): Turfs transplanted from high to low elevation lost species successively and did not differ in species richness from the low elevation controls at the end of the experiment $(P=0.282$; Fig. 5a). Although turfs transplanted from low to high gained species over time, they still had fewer species compared to high elevation controls at the end of the experiment $(P=0.031$; Fig. 5a). Turfs transplanted from mid to low elevations were intermediate in species richness between the low and mid elevation controls $(P=0.040$, Fig. 5c). Turfs transplanted from low to mid elevation gained species over time and had more 
species than the low elevation controls $(P=0.015)$, and did not differ significantly in richness from the controls of their new elevation $(P=0.099$, Fig. 3c).

No species other than those already growing in the meadow at the start of the experiment invaded the turfs during the 6 years; exotic species were absent. In all ordinations of the site scores based on species data, the first axis was strong with eigenvalues ranging between 0.50 and 0.87 (Fig. 6), mainly representing the riparian elevation gradient. The control plots of the three different elevations were all significantly different in community composition from each other, both the first and last year of the experiment $(P<0.05$, one-way ANOVA; Fig. 6). Although the site scores of the transplants had become more similar to the target elevation during the course of the experiment, only the transplantation from high to low was statistically indistinguishable from the community composition of control plots at the new elevation $(P>0.05$, one-way ANOVA; Fig. 6a). In the remaining cases, species composition of the transplants was intermediate between original and target levels (Fig. 6b, d and e), or was statistically similar to the original levels (Fig. 6c and f). 


\section{Discussion}

Our experiment demonstrates that riparian-plant communities will change in response to the hydrologic alterations expected as a result of climate change. This study also shows the importance of conducting long-term field experiments (Milchunas \& Lauenroth 1995). Plant communities had not fully adjusted to the new elevation 6 years after transplantation. Extrapolating from our results suggests that full adjustment to the new hydrological regime will take at least 10 years. However, rare events such as unusually large floods or droughts may result in non-linear vegetation responses (Jentsch et al. 2007).

\section{Hydrology}

Flood duration during the experiment for the mid and high elevation plots was in many respects intermediate between the normal period 1961-1990 and the projections for 2071-2100, implying that the observed warming during the last decades has led to hydrological trends going in the direction of the changes expected at the end of the century as a result of warming (Peterson et al. 2002). We conducted the experiment during a period which was drier and with shorter floods at all elevations compared to 1961-1990 (Table 1). Although inundation duration at the low elevation in 2001 was long in comparison with other years during the experiment, lasting from May to July, it was close to the average for 1961-1990.

\section{Effects of trenching}

The fact that the only significant effect of trenching was on biomass the second year suggests that excavation had limited effects and that excavated plots could be used as realistic controls for transplantation effects. The effect of trenching on biomass was probably caused by damage to below-ground plant parts. The fact that high-elevation trenched turfs had 
significantly more biomass than the controls in 2001, may be due to reduced soil competition from neighbouring plants outside the plots. Coomes \& Grubb (2000) suggested that root trenching would enhance growth when nutrients and/or water are limiting, and found support for this hypothesis in a review of experiments. In contrast, where soils are relatively rich and droughts are uncommon, trenching effects were weak or absent (Coomes \& Grubb 2000). The reduced biomass on the low-elevation transplants was likely a response to the combined effect of long duration of inundation in 2001 and lower tolerance to flooding after root damage. Complete submergence slows down growth even in inundation-tolerant species (Johansson \& Nilsson 2002; Voesenek et al. 2006) and water entrance into root aerenchyma following trenching might have further reduced growth. Also the turfs transplanted down from the high and mid elevations decreased substantially in biomass the same year (Fig. 5).

\section{Effects of hydrologic changes}

Why did biomass generally increase when turfs were transplanted to lower elevations? Growth at low elevations might have been enhanced by environmental conditions, such as higher soil moisture, or species on transplanted turfs were replaced with species that grow larger. In general, above-ground biomass of herbs and graminoids is high in low-lying riparian and other wetland plant communities where light availability is high and water does not limit growth (strongly nutrient limited communities excepted). The fact that biomass increased successively from 2001 to 2006 in plots transplanted from high to low elevations suggests that successive species replacement was the cause. In 2005 these plots were dominated by Calamagrostis canescens and Carex acuta (on average $96 \%$ of the total biomass). Both of these species were absent before transplantation. In contrast, the reason why turfs transplanted from low to high elevations decreased in biomass the first year after transplantation and remained low thereafter is better explained by the change in external 
conditions. The two species dominating turfs of low origin, Calamagrostis canescens and Carex acuta, remained high in frequency at high elevations, but decreased in biomass production, dropping from $206 \mathrm{~g}$ to $74 \mathrm{~g}$ and $260 \mathrm{~g}$ to $17 \mathrm{~g}$, respectively, between 2002 and 2005 , potentially as a result of drought stress. In the long run, they are likely to be outcompeted by more drought-tolerant species, given the existence of a trade-off between flooding and drought tolerances (Luo et al. 2008).

The slow adjustment in species composition following transplantation was probably caused by the ability of many species to tolerate hydrologic conditions distinct from those in unmanipulated systems (van Eck et al. 2004). The persistence of many species likely delayed or inhibited establishment of species better adapted to the conditions at the target elevations. Even in the case of transplanting from high to low elevations, where one might expect that flood duration would exceed the tolerance of high-elevation species, species losses occurred gradually over many years (Fig. 5a). Thus, long-term experiments are needed to evaluate the potential effects of hydrologic change on riparian ecosystems. Most ecological field experiments rarely last more than 3 years, which may be inadequate to draw conclusions about mechanisms controlling natural ecosystems, and treatment effects may change with time (Milchunas \& Lauenroth 1995). Even our 6-year study was too short for plant communities to fully adjust to the new conditions imposed by the experiment.

Catastrophic events, such as hurricanes or floods, can trigger permanent changes to ecosystems by causing widespread mortality, allowing new species to establish. Flooding events of exceptional duration have been shown to severely decrease species richness in riparian zones (Renöfält et al. 2007) and alter limits of riparian vegetation belts (Vervuren et al. 2003; van Eck et al. 2004). If such an event had occurred during our experiment, rapid 
adjustments in species composition may have resulted. The importance of events rather than gradual changes in biotic responses to climate change has recently been emphasized (Jentsch et al. 2007).

\section{The future of riparian vegetation in the Vindel River}

Combining the results of the transplant experiment and projections of future stream flows, we may predict likely responses of riparian vegetation to climate-driven hydrologic changes. The high riparian elevations in the experiment are projected to experience less frequent flooding (Table 1) and are expected to shift into terrestrial forest communities likely to lose most riparian species with time. Differences in species richness between riparian and terrestrial plant communities in the region are dramatic, with forest understories being dominated by a few dwarf-shrub species (Nilsson \& Jansson 1995). The boundary between riparian and terrestrial plant communities is generally sharp, occurring over a few decimetres in elevation and coinciding with the limit of floods occurring every second year (Nilsson 1983). For the middle-elevation communities, the projected frequency of flooding resembles present ones at the high elevation. Hence, the transplantation of turfs from middle to high elevation is relevant to predict likely effects of climate change to mid-elevation plant communities. There were no significant responses in biomass or species richness of mid-to-high transplants, implying that mid-elevations will mainly change in species composition to constitute the highest part of the regularly flooded riparian zone, representing a decline in the area of species-rich spring-flood communities.

\footnotetext{
All four climate-change scenarios predict an overall increase in river runoff in the boreal part of Sweden between 1961-1990 and 2071-2100 (Andréasson et al. 2004). The largest flow increases will occur outside the growing season when water levels are below summer low
} 
water-levels coinciding with the lower limit of continuous Carex vegetation (Fig. 7), and are thus expected to primarily impact amphibious plant communities. However, low-elevation Carex communities may become flooded any time of the year in the future, with effects difficult to predict. For example, ice disturbance during winter floods may become common. If inundation of low-elevation, Carex-dominated communities would increase as suggested in the more extreme projections (Fig. 7), present communities may become replaced by amphibious plant communities. The low elevation was inundated on average 20 days shorter per year during the experiment compared to the period 1961-1990 (37.4 days compared to 57.0 days; Table 1), implying that the contrast between present and projected future conditions is larger than shown in Fig. 7. To conclude, we predict that climate-driven hydrologic changes will result in narrower riparian zones along the Vindel River, with present riparian-plant communities being replaced by terrestrial communities at the top and by amphibious or aquatic communities at the bottom. Given strong species-area relations, less area available to riparian plants is expected to reduce species richness, even if no species lose their hydrologic niches.

\section{Predicting the effects of climate change in different boreal regions}

Hydrologic changes caused by a warmer climate are expected to vary across boreal and Arctic regions (Woo et al. 2008) as a result of regional differences in climate change and differences in characteristics between catchments. The hydrologic response will vary depending on the proportion of precipitation expected to fall as snow in the future, the overall trend in the amount of precipitation, and the balance between precipitation and evapotranspiration (Woo et al. 2008). Most northern rivers will get a significant proportion of the precipitation as snow also in the future, either because they lie in the far north or because they drain high mountain ranges. Effects of hydrologic change on such rivers are expected to be similar to the ones 
predicted for the Vindel River, with reductions in spring flood height and higher winter flows. The magnitude of change is expected to vary latitudinally, with the smallest changes in northernmost rivers. High Arctic rivers may even experience higher spring floods as a result of higher precipitation and more snow accumulation.

Rivers in the southern parts of the boreal zone with catchments lacking large alpine areas will experience significant decreases in the proportion of precipitation falling as snow. The qualitative hydrologic changes will be similar to the Vindel River, but be more extreme: Spring floods will have lower magnitudes or disappear, resulting in losses or reductions in the area of riparian forest communities, with subsequent losses in riparian species richness. In addition, water-levels will vary less among seasons, with higher winter flows, resulting in upward displacements of low-elevation riparian zonation, amphibious and aquatic plant communities replacing herbs and graminoids. In boreal continental-climate regions, warming is expected to lead to more extreme summer humidity deficits, resulting in decreased summer flows and more drought stress, which may reduce riparian biomass production and alter competitive relations among species. This might correspond to transplanting turfs to higher elevations, and hence result in biomass losses and local species-richness increases. However, we do not know how the effect of summer droughts will combine with other climate-change effects, such as reduced spring flooding or higher frequency of autumn floods.

Increases in the occurrence of major rain storms have been implicated as a result of warming (Ilg et al. 2008). Andréasson et al. (2004) predicted a general increase in the frequency of 100 -year floods in autumn for northern Sweden at the end of the century. Given that extreme floods of long duration have long-lasting effects on riparian plant communities, e.g. by causing extinctions of flood-sensitive species (Renöfält et al. 2007), increases in the 
frequency of such events may have profound effects. If more frequent than the recovery time, a reduction in average diversity is expected.

Riparian plant communities make up a significant proportion of regional plant diversity in boreal landscapes (Nilsson \& Jansson 1995; Renöfält et al. 2005), and the predicted losses in the area of riparian zones may thus have landscape-level consequences. A number of actions may be taken to reduce the risk of riparian species loss. First, remaining species-rich areas may be managed to ensure long-term viability of component species. Second, streams and rivers degraded by dams and channelization may be restored to increase the abundance of riparian species. Third, further studies are required to identify species especially at risk, for which actions to maintain their population size may be warranted. Specifically, information about the hydrologic requirements of individual riparian plant species is needed to predict their climate-change responses. Finally, riparian zones perform many ecosystem functions important for other landscape elements, such as supplying wood and leaf litter to aquatic habitats and acting as a buffer against flows of matter and pollutants from terrestrial areas to streams (Naiman et al. 2005). Elucidating how these riparian functions are affected by climate-driven hydrologic change is a priority area for research. 


\section{Acknowledgments}

We thank Johan Andréasson for providing us with hydrologic data, Elisabet Carlborg, Pia Hansson and Magnus Svedmark for assistance in the field and David Merritt for valuable comments on the manuscript. Funding for the study was provided by the Swedish Research Council Formas (to C. Nilsson and R. Jansson). 


\section{References}

Andréasson J, Bergström S, Carlsson B, Graham P, Lindström G (2004) Hydrological change: climate change impact simulations for Sweden. Ambio, 33, 228-234.

Auble GT, Friedman JM, Scott ML (1994) Relating riparian vegetation to present and future streamflows. Ecological Applications, 4, 544-554.

Bendix J (1999) Stream power influence on southern Californian riparian vegetation. Journal of Vegetation Science, 10, 243-252.

Coomes DA, Grubb PJ (2000) Impacts of root competition in forests and woodlands: a theoretical framework and review of experiments. Ecological Monographs, 70, 171-207.

Dankers R, Middelkoop H (2008) River discharge and freshwater runoff to the Barents Sea under present and future climate conditions. Climatic Change, 87, 131-153.

Day RT, Keddy PA, McNeil J, Carleton T (1988) Fertility and disturbance gradients: a summary model for riverine marsh vegetation. Ecology, 69, 1044-1054.

Décamps H (1993) River margins and environmental change. Ecological Applications, 3, 441-445.

Dynesius, M, Jansson, R, Johansson, ME, Nilsson, C (2004) Intercontinental similarities in riparian-plant diversity and sensitivity to river regulation. Ecological Applications, 14, 173-191.

Dwire, KA, Kauffman, JB, Brookshire, ENJ, Baham, JE (2004) Plant biomass and species composition along an environmental gradient in montane riparian meadows. Oecologia, 139, 309-317.

Ilg C, Dziock F, Foeckler F, et al. (2008) Long-term reactions of plants and macroinvertebrates to extreme floods in floodplain grasslands. Ecology, 89, 2392-2398. 
IPCC (2007) Climate Change 2007: The Physical Science Basis. Contribution of Working Group I to the Fourth Assessment Report of the Intergovernmental Panel on Climate Change (eds Solomon S, Qin D, Manning M, et al.). Cambridge University Press, Cambridge, UK.

Jentsch A, Kreyling J, Beierkuhnlein C (2007) A new generation of climate-change experiments: events, not trends. Frontiers in Ecology and the Environment, 5, 365-374. Johansson ME, Nilsson C (2002) Responses of riparian plants to flooding in free-flowing and regulated boreal rivers: an experimental study. Journal of Applied Ecology, 39, 971-986.

Kozlowski TT (1984) Responses of woody plants to flooding. In Flooding and Plant Growth (ed. Kozlowski TT), pp 129-163. Academic Press, San Diego, CA, USA.

Krok TOBN, Almquist S (1994) Svensk Flora. Fanerogamer och Ormbunksväxter. 27th edn. Liber Utbildning, Stockholm, Sweden.

Luo WB, Song FB, Xie YH (2008) Trade-off between tolerance to drought and tolerance to flooding in three wetland plants. Wetlands, 28, 866-873.

Milchunas DG, Lauenroth WK (1995) Inertia in plant community structure: state changes after cessation of nutrient enrichment stress. Ecological Applications, 5, 452-458.

Mommer L, Visser EJW (2005) Underwater photosynthesis in flooded terrestrial plants: a matter of leaf plasticity. Annals of Botany, 96, 581-589.

Naiman, RJ, Bunn SE, Nilsson C, Petts GE, Pinay G, Thompson LC (2002) Legitimizing fluvial ecosystems as users of water: an overview. Environmental Management, 30, $455-467$.

Naiman RJ, Décamps H (1997) The ecology of interfaces: riparian zones. Annual Review of Ecology and Systematics, 28, 621-658. 
Naiman RJ, Décamps H, McClain ME (2005) Riparia: Ecology, Conservation and Management of Streamside Communities. Elsevier/Academic Press, San Diego, CA, USA.

Nakicenovic N, Swart R (2000) Special Report on Emissions Scenarios. Cambridge University Press, Cambridge, UK.

Nilsson C (1983) Frequency distributions of vascular plants in the geolittoral vegetation along two rivers in northern Sweden. Journal of Biogeography, 10, 351-369.

Nilsson C (1999) Rivers and streams. In Swedish Plant Geography (eds Rydin H, Snoeijs P, Diekmann M), pp. 135-148. Opulus Press, Uppsala, Sweden.

Nilsson C, Jansson R (1995) Floristic differences between riparian corridors of regulated and free-flowing boreal rivers. Regulated Rivers: Research and Management, 11, 55-66.

Nilsson C, Reidy CA, Dynesius M, Revenga C (2005) Fragmentation and flow regulation of the world's large river systems. Science, 308, 405-408.

Peterson BJ, Holmes RM, McClelland JW, et al. (2002) Increasing river discharge to the Arctic Ocean. Science, 298, 2171-2173.

Poff NL, Allan JD, Bain MB, et al. (1997) The natural flow regime. BioScience, 47, 769-784.

Pollock MM, Naiman RJ, Hanley TA (1998) Plant species richness in riparian wetlands: a test of biodiversity theory. Ecology, 79, 94-105.

Post E, Forchhammer MC, Bret-Harte MS, et al. (2009) Ecological dynamics across the Arctic associated with recent climate change. Science, 325, 1355-1358.

R Development Core Team (2006). R: a Language and Environment for Statistical Computing. Version 2.4.0. The R Foundation for Statistical Computing, ISBN-3900051-07-0. 
Renöfält BM, Merritt DM, Nilsson C (2007) Connecting variation in vegetation and stream flow: the role of geomorphic context in vegetation response to large floods along boreal rivers. Journal of Applied Ecology, 44, 147-157.

Renöfält BM, Nilsson C, Jansson R (2005) Spatial and temporal patterns of species richness in a riparian landscape. Journal of Biogeography, 32, 2025-2037.

Saetersdal M, Birks HJB, Peglar SM (1998) Predicting changes in Fennoscandian vascularplant species richness as a result of future climatic change. Journal of Biogeography, 25, 111-122.

Sharitz RR, Boring LR, Van Lear DH, Pinder III JE. (1992) Integrating ecological concepts with natural resource management of southern forests. Ecological Applications, 2, $226-237$.

Silvertown J, Dodd ME, Gowing DJG, Mountford JO (1999) Hydrologically defined niches reveal a basis for species richness in plant communities. Nature, 400, 61-63.

ter Braak CJF, Smilauer P (1998) CANOCO Reference Manual and User's Guide to Canoco for Windows: Software for Canonical Community Ordination (version 4). Microcomputer Power, Ithaca, NY, USA.

Thuiller W, Lavorel S, Araujo MB, Sykes MT, Prentice IC (2005) Climate change threats to plant diversity in Europe. Proceedings of the National Academy of Sciences of the United States of America, 102, 8245-8250.

Toogood SE, Joyce CB, Waite S (2008) Response of floodplain grassland plant communities to altered water regimes. Plant Ecology, 197, 285-298.

van Eck W, van de Steeg HM, Blom C, de Kroon H (2004) Is tolerance to summer flooding correlated with distribution patterns in river floodplains? A comparative study of 20 terrestrial grassland species. Oikos, 107, 393-405. 
Vervuren PJA, Blom C, de Kroon H (2003) Extreme flooding events on the Rhine and the survival and distribution of riparian plant species. Journal of Ecology, 91, 135-146.

Voesenek L, Colmer TD, Pierik R, Millenaar FF, Peeters AJM (2006) How plants cope with complete submergence. New Phytologist, 170, 213-226.

Wassén G (1966) Gardiken. Vegetation und Flora eines Lappländischen Seeufers. Kungliga Svenska Vetenskapsakademiens Avhandlingar i Naturskyddsärenden, 22, 1-142.

Woo MK, Thorne R, Szeto K, Yang DQ (2008) Streamflow hydrology in the boreal region under the influences of climate and human interference. Philosophical Transactions of the Royal Society B - Biological Sciences, 363, 2251-2260.

Xiong SJ, Nilsson C (1997) Dynamics of leaf litter accumulation and it effects on riparian vegetation: a review. Botanical Review, 63, 240-264. 


$$
\begin{aligned}
& \text { Table } 1 \text { Flooding regime for each elevation. Values from our study and from 1961-1990 were from data } \\
& \text { loggers or a nearby gauge, whereas the four scenarios for 2071-2100 were calculated from hydrologic data } \\
& \text { presented by the Swedish Meteorological and Hydrological Institute (Norrköping, Sweden). RT = Return time, } \\
& \text { Duration = number of flooded days per year. Model abbreviations are explained in the Methods section. }
\end{aligned}
$$

\begin{tabular}{|c|c|c|c|c|c|c|c|c|c|c|}
\hline \multirow[b]{4}{*}{ Period } & \multirow[b]{4}{*}{ Years } & \multicolumn{9}{|c|}{ Riparian elevation } \\
\hline & & \multicolumn{3}{|c|}{ Low } & \multicolumn{3}{|c|}{ Mid } & \multicolumn{3}{|c|}{ High } \\
\hline & & \multirow[b]{2}{*}{$\mathrm{RT}$} & \multicolumn{2}{|c|}{ Duration } & \multirow[b]{2}{*}{$\mathrm{RT}$} & \multicolumn{2}{|c|}{ Duration } & \multirow[b]{2}{*}{$\mathrm{RT}$} & \multicolumn{2}{|c|}{ Duration } \\
\hline & & & mean & range & & mean & range & & mean & range \\
\hline \multicolumn{11}{|l|}{ Observed data } \\
\hline $2000-2006$ & 7 & 1 & 37.4 & $16-81$ & 1.4 & 6.9 & $0-14$ & 3.5 & 1.7 & $0-7$ \\
\hline $1961-1990$ & 30 & 1 & 57.0 & $28-100$ & 1.3 & 9.7 & $0-26$ & 2.1 & 2.8 & $0-12$ \\
\hline \multicolumn{11}{|l|}{ Models } \\
\hline ECHAM4-B2 & 30 & 1 & 67.2 & $30-108$ & 1.6 & 6.1 & $0-27$ & 6.0 & 1.7 & $0-22$ \\
\hline HadAM3H-B2 & 30 & 1 & 58.0 & $28-99$ & 2.3 & 5.0 & $0-26$ & 7.5 & 1.3 & $0-21$ \\
\hline ECHAM4-A2 & 30 & 1 & 75.2 & $29-126$ & 2.5 & 4.4 & $0-23$ & 7.5 & 1.0 & $0-10$ \\
\hline HadAM3H-A2 & 30 & 1 & 56.0 & $18-95$ & 2.7 & 2.9 & $0-24$ & 7.5 & 0.9 & $0-10$ \\
\hline
\end{tabular}


Table 2 Effects of transplantations and the litter addition of 2001 and 2002, factorial ANOVA. Df for 2002-2006 is the same as for $2001 . * * * P<0.001, * * P<0.01, * P<0.05$

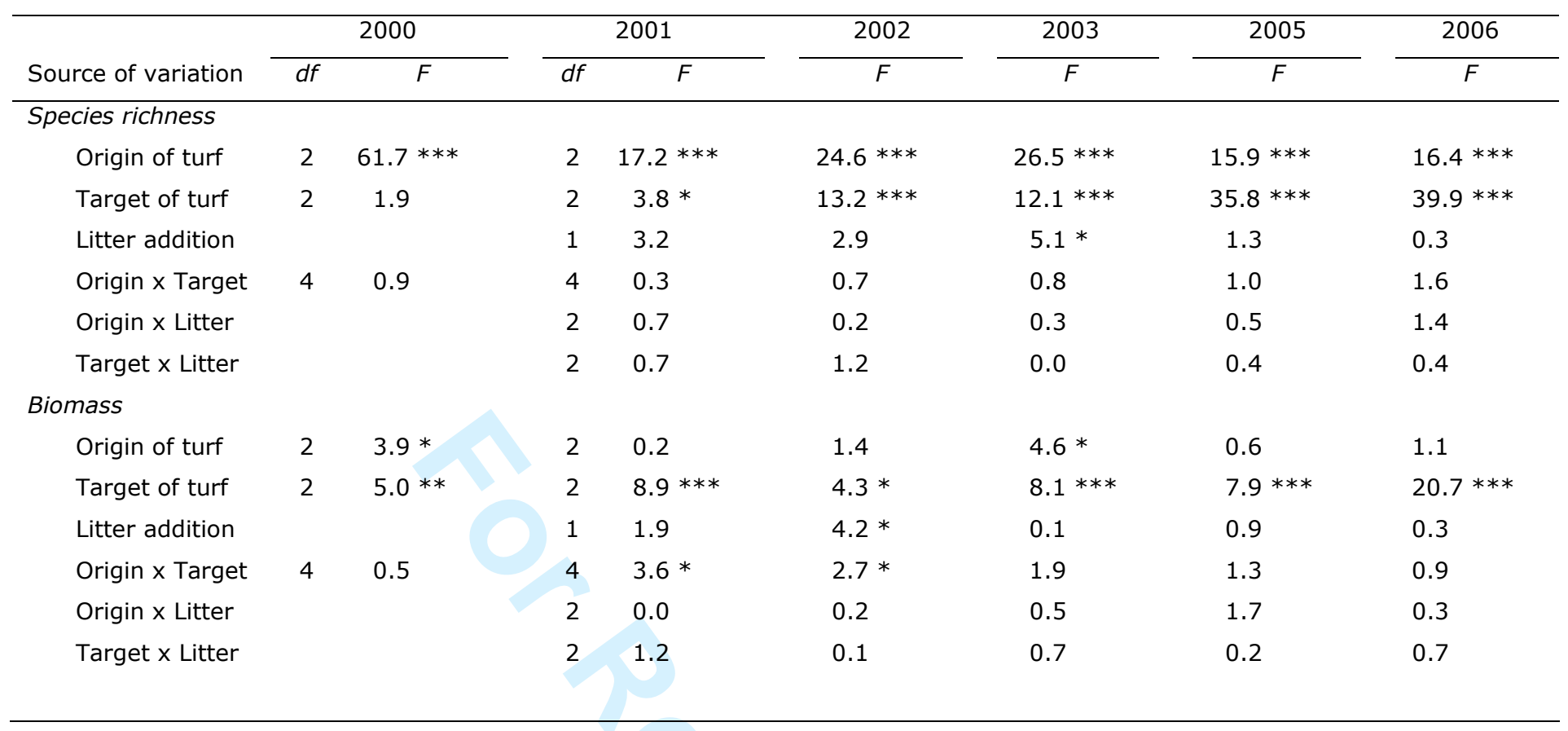


Fig. 1 Schematic illustration of the experimental setup showing one of eight replicates along with the spatial arrangement of vegetation data sampling within a plot. Arrows indicate how turfs were transplanted between levels. There were four blocks, giving a total of 96 plots in the experiment. Only one of the subplots for biomass sampling was harvested each year. 
Fig. 2 Number of days of flooding per year at each elevation in the riparian zone during the experiment. 
1

Fig. 3 Relative changes in biomass (a, c and e) and species richness (b, d and f) between 2000 and 2006 (means \pm 2 SE) compared among turfs from a specific level of origin (high, mid and low) depending on their target level after transplantation (high, mid and low). Lowercase letters indicate significant differences between the responses of the turfs to the new elevation according to one-way ANOVAs and post-hoc tests (Tukey's honest significant difference; $P<0.05$ ). 
Fig. 4 Temporal change in biomass per plot (mean \pm SE) transplanted between (a) high and low, (b) high and mid, and (c) mid and low levels. Treatments are denoted according to their elevation in the riparian zone (low, mid and high transplantation controls), or between which levels they were transplanted (e.g. high to low). The plots were not sampled in 2004. Lowercase letters indicate significant differences among treatments the final year according to one-way ANOVAs and posthoc tests (Tukey's honest significant difference; $P<0.05$ ). 
1

3

4

5

6

7

8

9

10

11

12

13

14

15

16

17

18

19

20

21

22

23

24

25

26

27

28

29

30

31

32

33

34

35

36

37

38

39

40

41

42

43

44

45

46

47

48

49

50

51

52

53

54

55

56

57

58

59

60

Fig. 5 Temporal change in species richness per plot (mean \pm SE) transplanted between (a) high and low, (b) high and mid, and (c) mid and low levels. Treatments are denoted according to their elevation in the riparian zone (low, mid and high transplantation controls), or between which levels they were transplanted. The plots were not sampled in 2004. Lowercase letters indicate significant differences among treatments the final year according to one-way ANOVAs and post-hoc tests (Tukey's honest significant difference; $P<0.05$ ). 
Fig. 6 Plots of site scores from the first two axes of detrended correspondence analyses showing the community composition of transplanted turfs in 2000 (open symbols) and in 2006 (filled symbols). Turfs from 2006 with the same treatment are enclosed, with solid lines indicating controls and dashed lines turfs transplanted between two levels. Lowercase letters indicate significant differences between groups along axis 1 according to one-way ANOVAs and post-hoc tests (Tukey's honest significant difference; $P<0.05$ ). Eigenvalues for axis 1 were: (a) 0.87 , (b) 0.87, (c) 0.50, (d) 0.55, (e) 0.61 and (f) 0.70 . 
Fig. 7 Average number of flooded days per month calculated from 30 year periods, based either on measured values for the period 1961-1990 (black line) or projected values for the period 2071-2100 according to climate change scenarios (gray lines). Climate models and scenarios are explained in the Methods section. 
Experimental setup

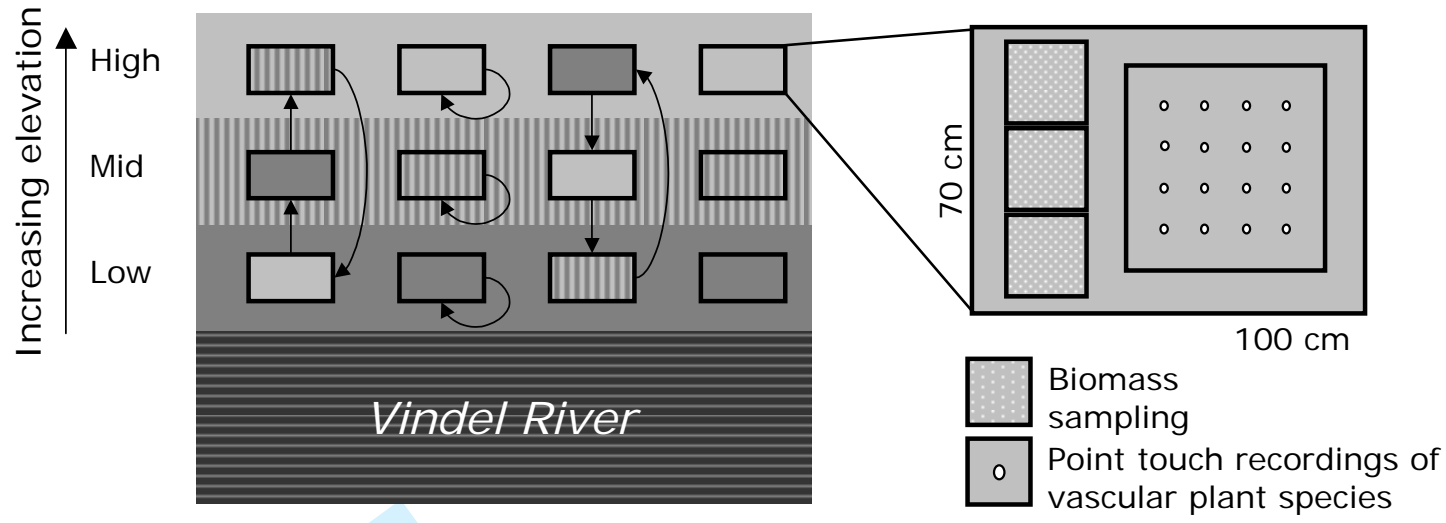




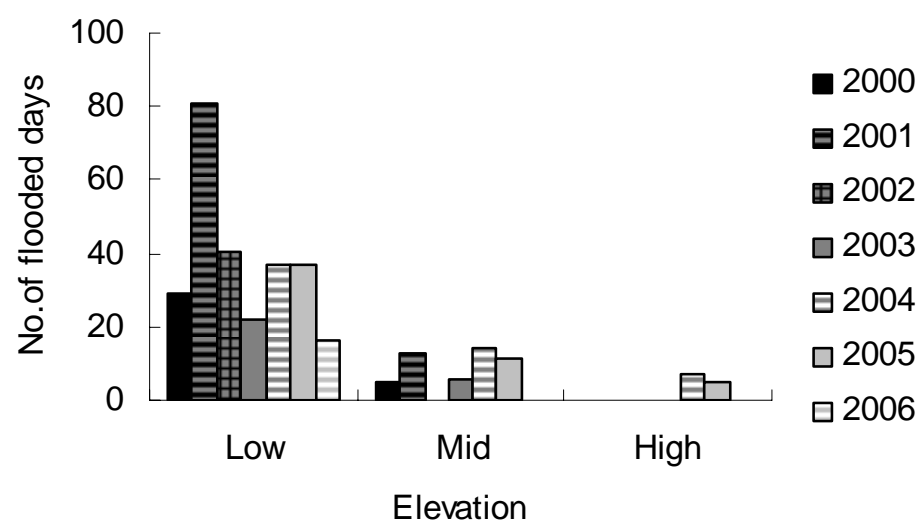


Biomass

High origin
No. of species

High origin (a)

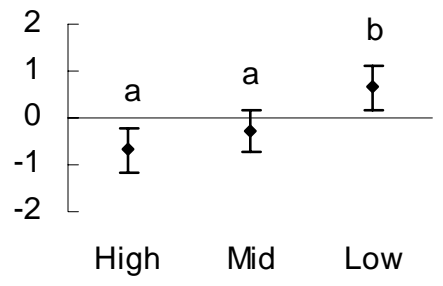

Mid origin

(c)

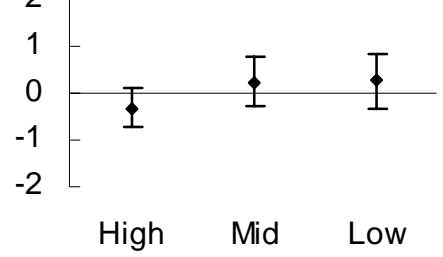

Low origin

(e) 2

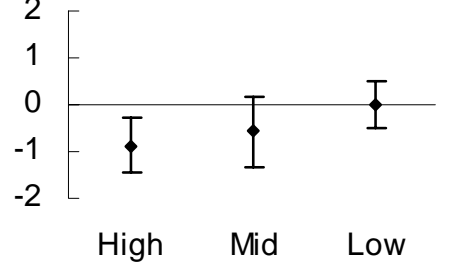

(b) 2

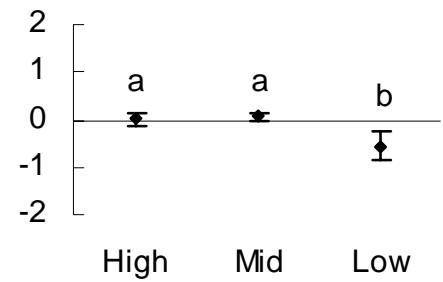

Mid origin

(d)

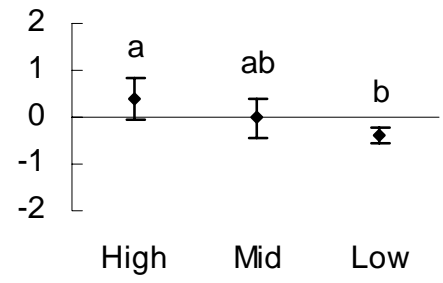

Low origin

(f) $2\left[\begin{array}{ll}a & a\end{array}\right.$

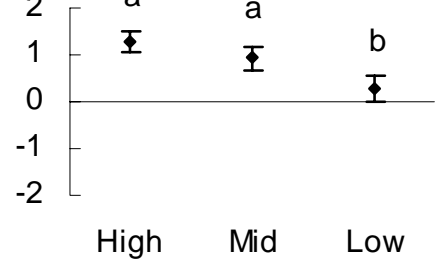

\section{Elevation after transplant}



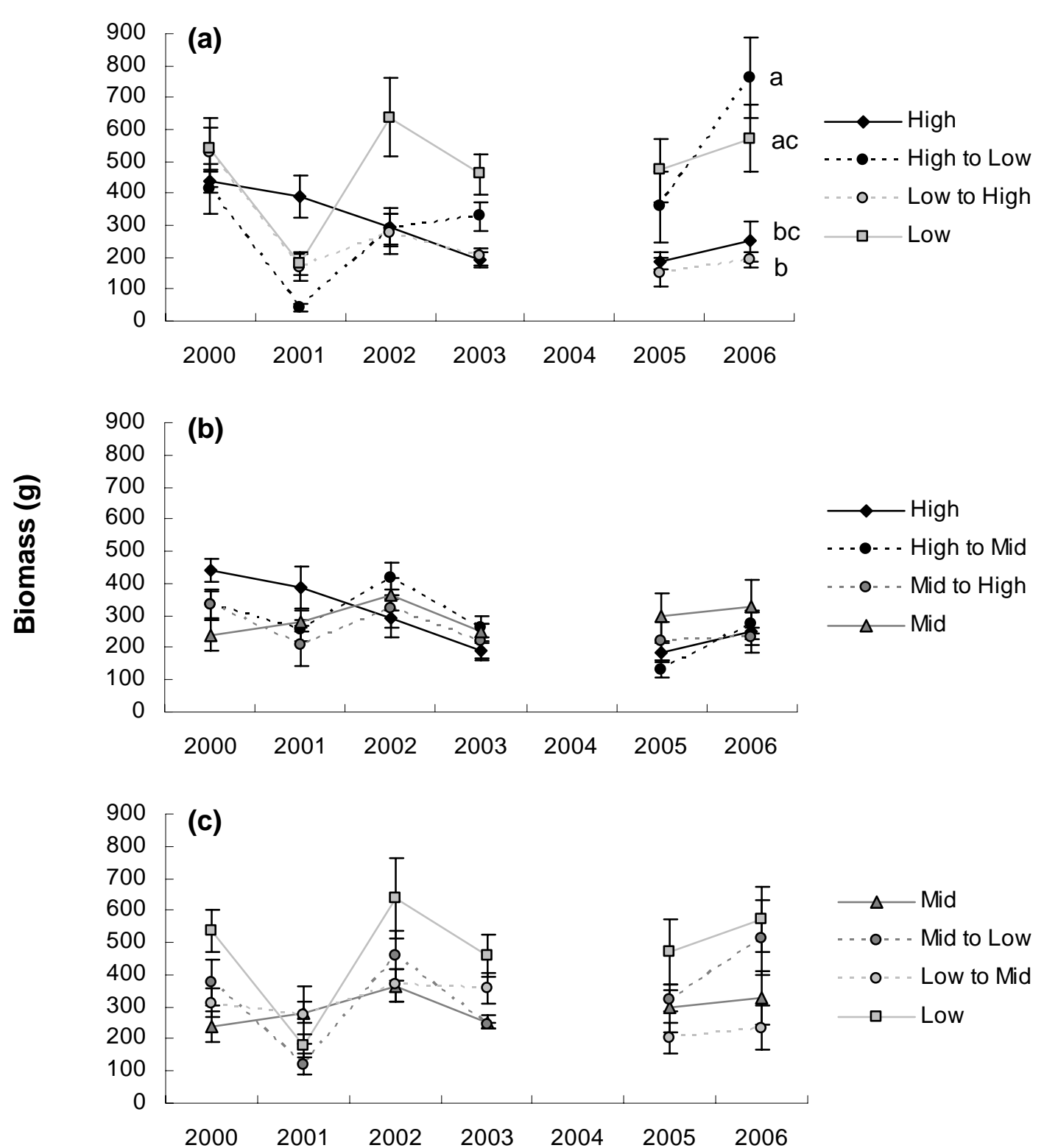

Year 
(a)
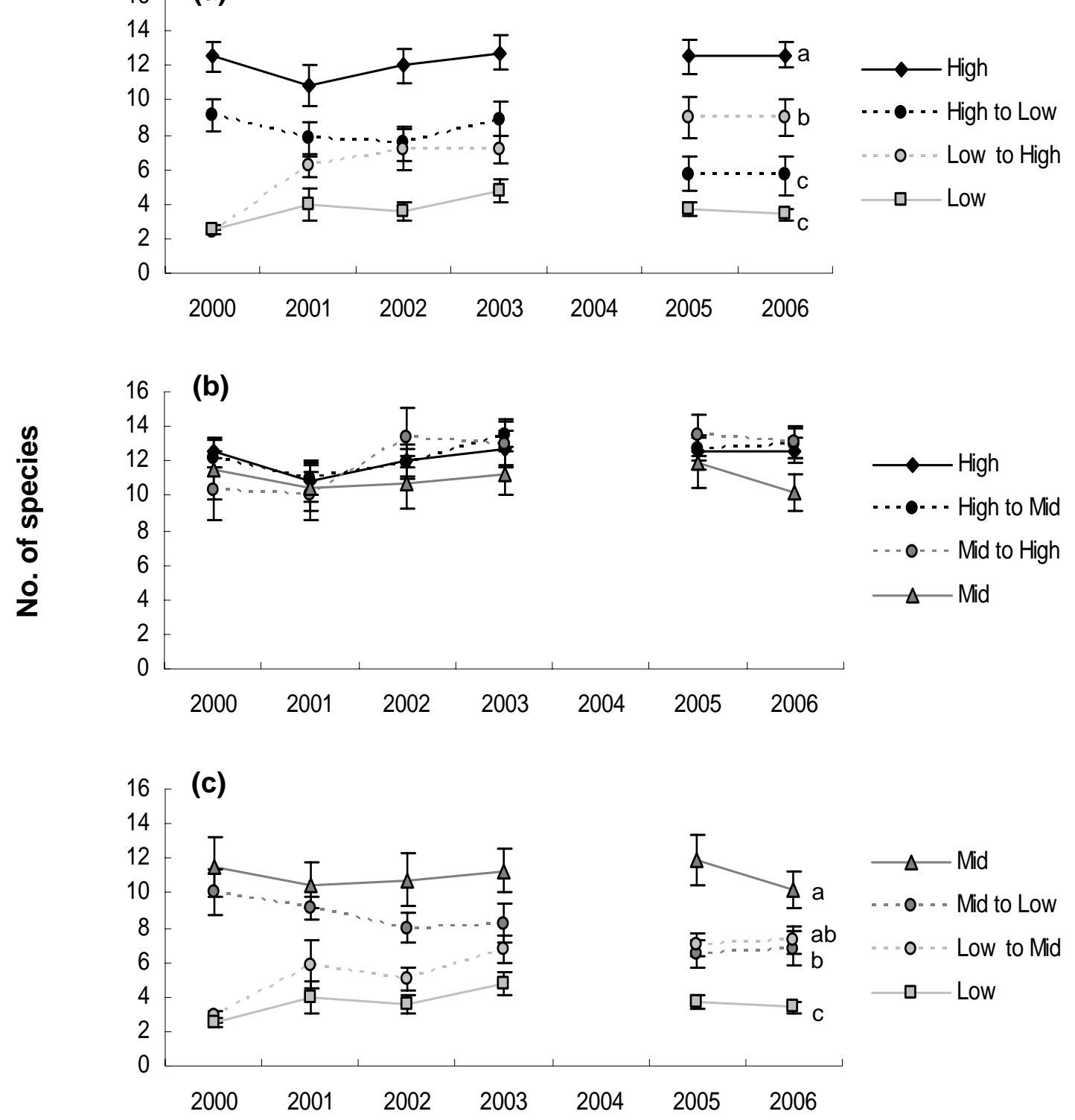

\section{Year}




\section{Page 45 of 45}

(a) ${ }^{3}$ Global Change Biology

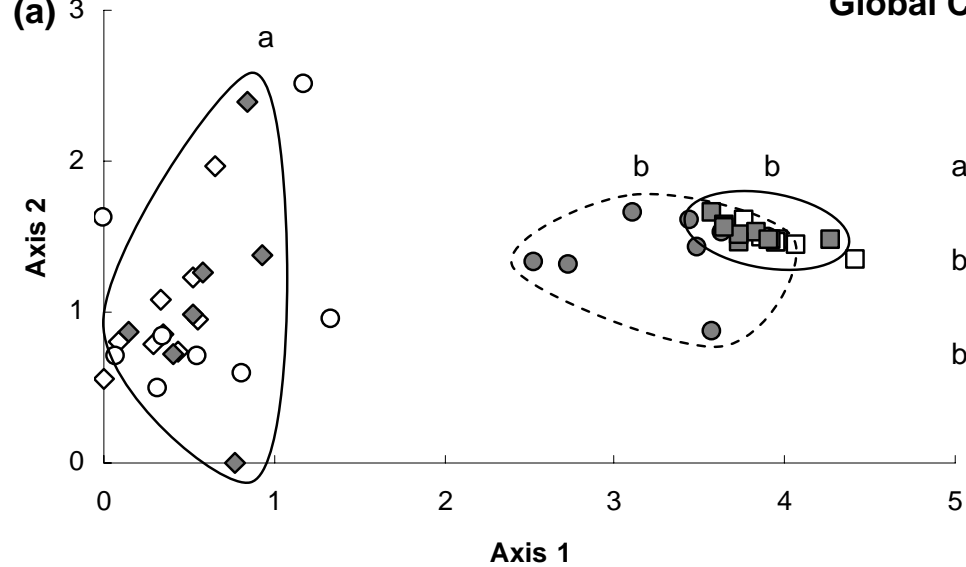

$\diamond$ High 00

a (2) High 06

o High to Low 00

b

口 Low 00

b (ㄷ)Low 06

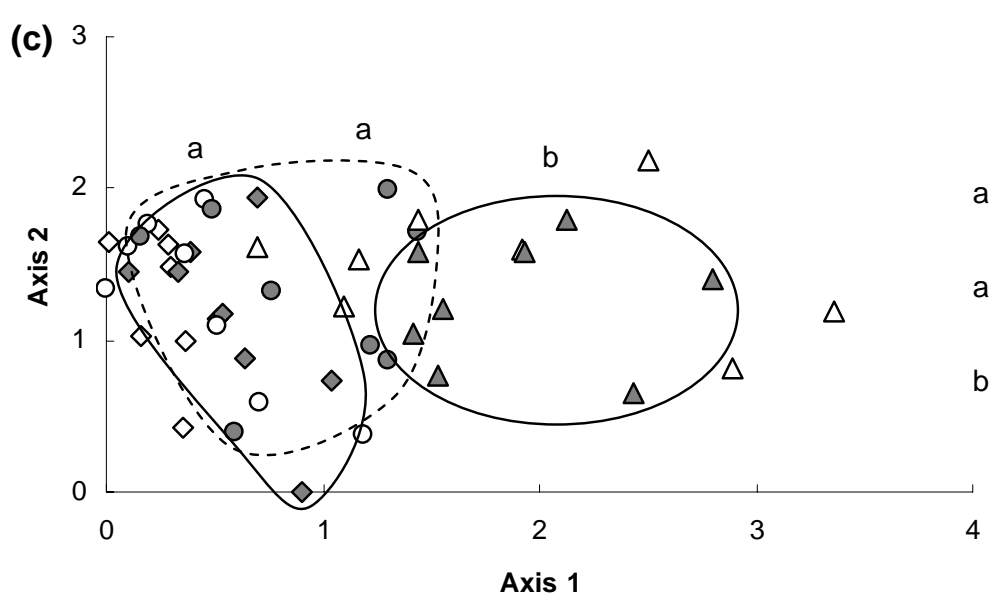

$\diamond$ High 00

a (-)High 06

- High to Mid 00

a

$\triangle$ Mid 00

(4) Mid 06

(e) 3

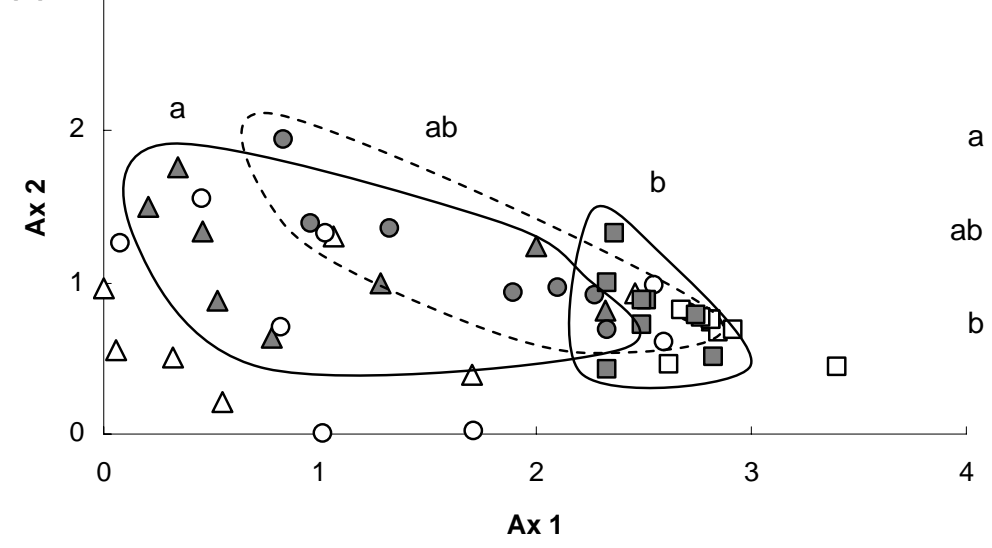

$\Delta$ Mid 00

○ Mid to Low 00

口 Low 00

bَ, Low 06 (b)

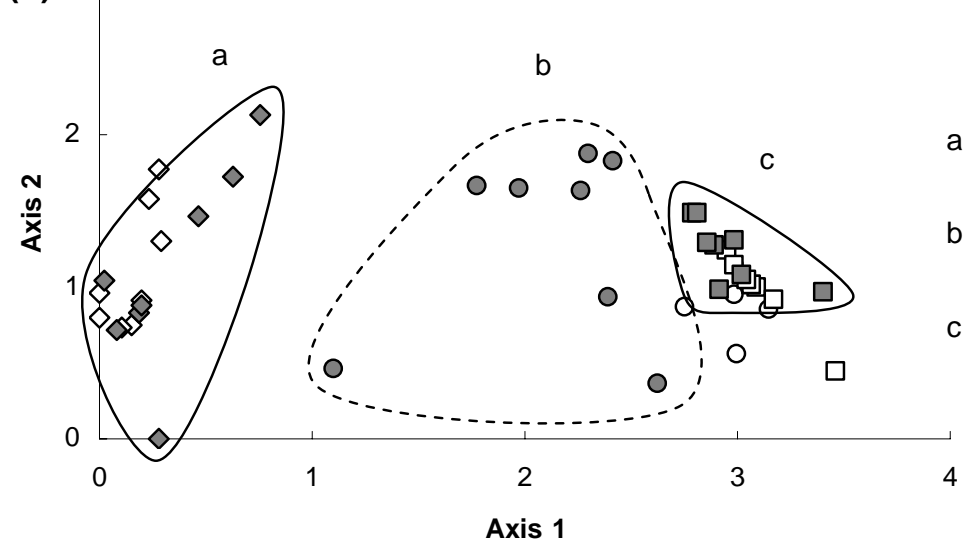

$\diamond$ High 00

a (2) High 06

- Low to High 00

b '́, Low to High 06

口 Low 00

c (ㅁ)Low 06

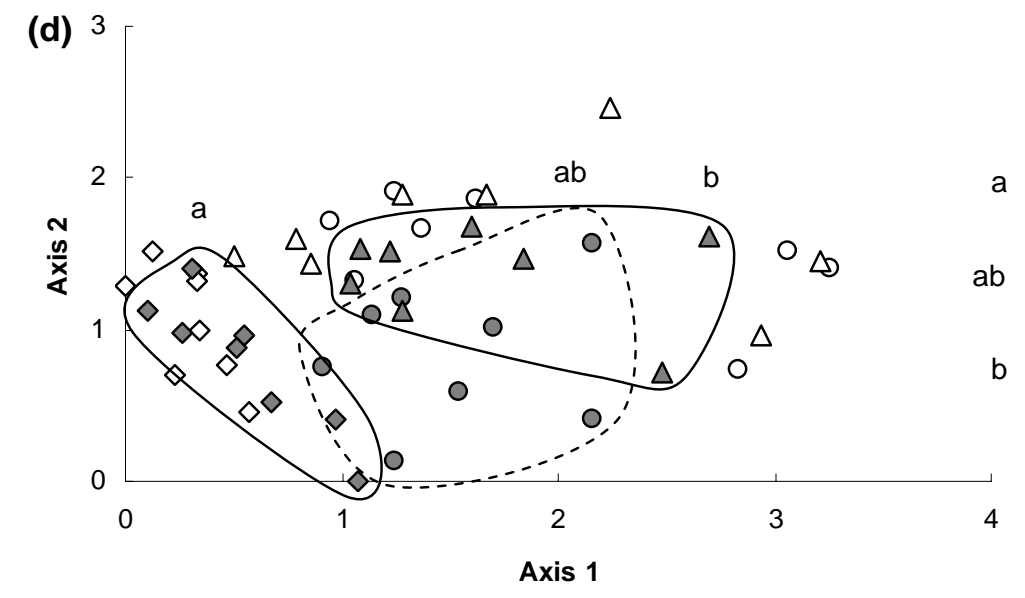

(f)

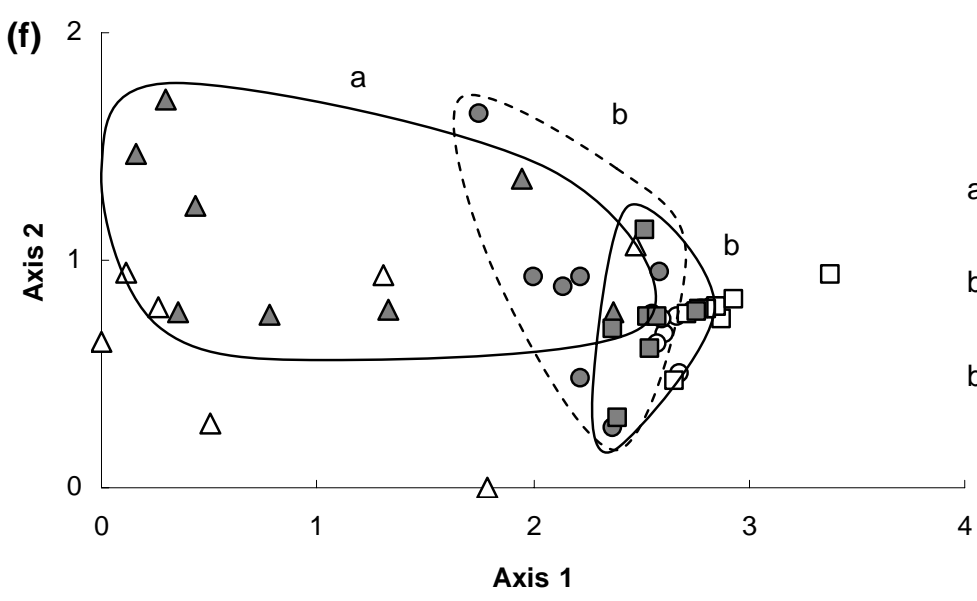

Axis 1 $\triangle$ Mid 00

a (ब) Mid 06

○ Low to Mid 00

b 'ó, Low to Mid 06 口 Low 00

b (D)Low 06
(2) High 06

o Mid to High 00

$\triangle$ Mid 00

$\Delta$ Mid 06 


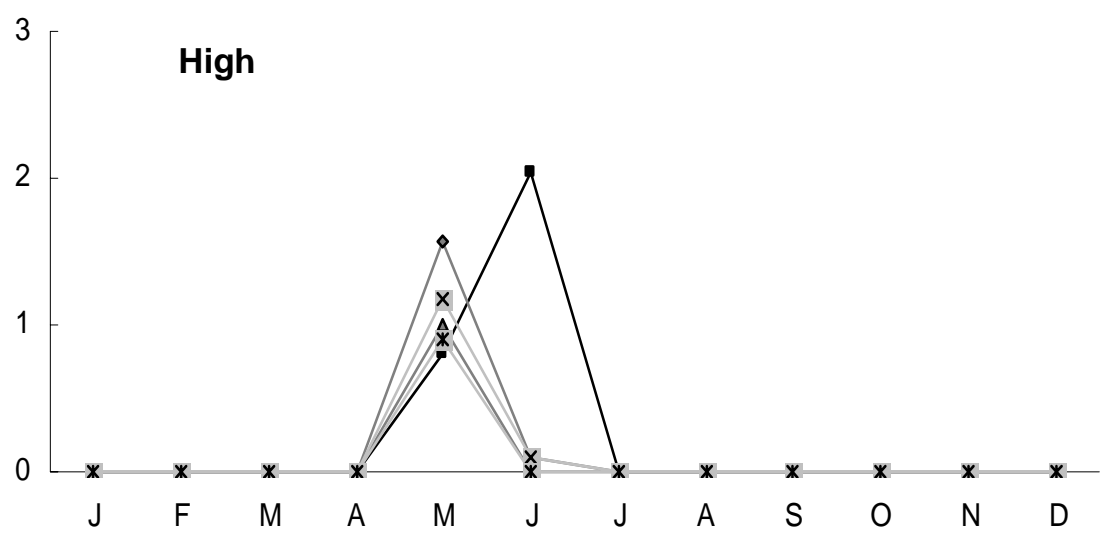

$\rightarrow$ 1961-1990

$\rightarrow$ ECHAM4-B2

$\triangle$ ECHAM4-A2

- - HadAM3H-B2

*- Had-A2

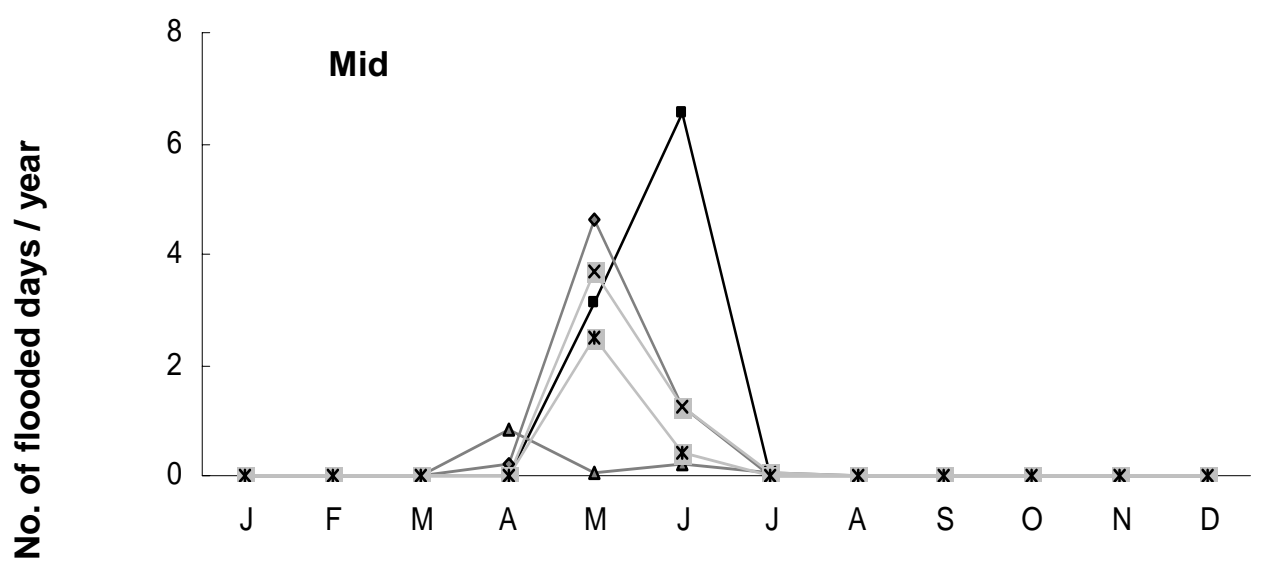

$\rightarrow$ 1961-1990

$\rightarrow$ ECHAMM-B2

$\triangle$ ECHAMA-A2

$-\mathbf{x}$ - HadAM3H-B2

* - Had-A2

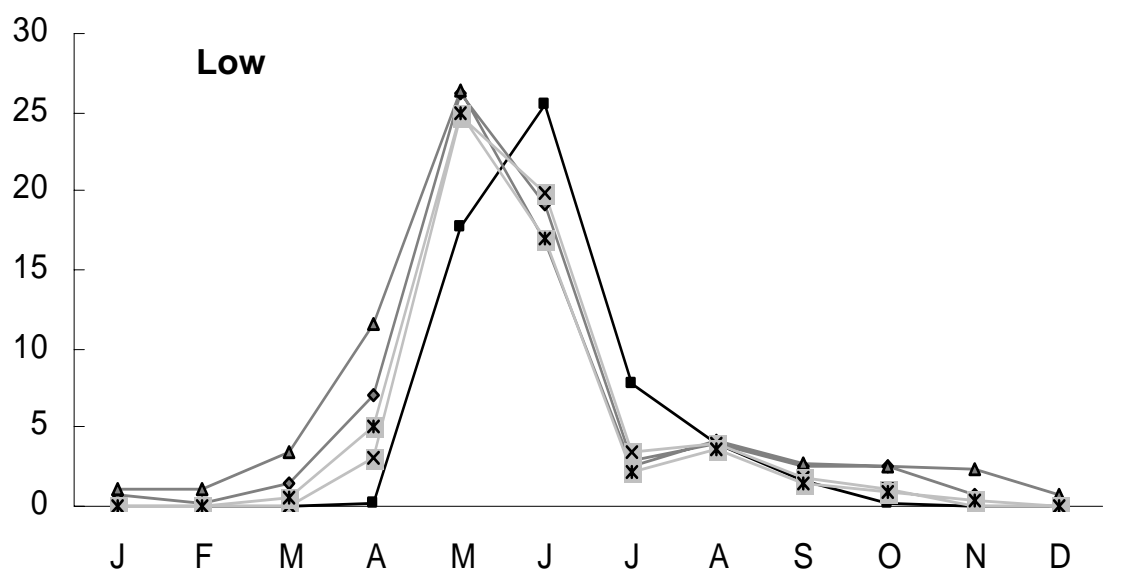

$\rightarrow$ 1961-1990

- ECHAM4-B2

$\triangle$ ECHAM4-A2

x- HadAM3H-B2

*- HadAM3H-A2

\section{Months}

